\title{
A Suite of TMPRSS2 Assays for Screening Drug Repurposing Candidates as Potential Treatments of COVID-19
}

Jonathan H. Shrimp ${ }^{1}$, John Janiszewski ${ }^{1}$, Catherine Z. Chen ${ }^{1}$, Miao Xu ${ }^{1}$, Kelli M. Wilson ${ }^{1}$, Stephen C. Kales ${ }^{1}$, Philip E. Sanderson ${ }^{1}$, Paul Shinn ${ }^{1}$, Zina Itkin ${ }^{1}$, Hui Guo ${ }^{1}$, Min Shen ${ }^{1}$, Carleen Klumpp-Thomas ${ }^{1}$, Samuel G. Michael ${ }^{1}$, Wei Zheng ${ }^{1}$, Anton Simeonov ${ }^{1}$, Matthew D. Hall ${ }^{* 1}$

${ }^{1}$ National Center for Advancing Translational Sciences, National Institutes of Health, Rockville, MD, 20850

*Correspondence to: Matthew D. Hall (hallma@mail.nih.gov)

Keywords: COVID-19, TMPRSS2, Antiviral, Drug Repurposing, High-Throughput Screening 


\section{Abstract}

SARS-CoV-2 is the causative viral pathogen driving the COVID-19 pandemic that prompted an immediate global response to the development of vaccines and antiviral therapeutics. For antiviral therapeutics, drug repurposing allowed for rapid movement of existing clinical candidates and therapies into human clinical trials to be tested as COVID-19 therapies. One effective antiviral treatment strategy used early in symptom onset is to prevent viral entry. SARS-CoV-2 enters ACE2-expressing cells when the receptorbinding domain of the spike protein on the surface of SARS-CoV-2 binds to ACE2 followed by cleavage at two cut sites on the spike protein. TMPRSS2 has a protease domain capable of cleaving the two cut sites; therefore, a molecule capable of inhibiting the protease activity of TMPRSS2 could be a valuable antiviral therapy. Initially, we used a fluorogenic high-throughput screening assay for the biochemical screening of 6030 compounds in NCATS annotated libraries. Then, we developed an orthogonal biochemical assay that uses mass spectrometry detection of product formation to ensure that hits from the primary screen are not assay artifacts from the fluorescent detection of product formation. Finally, we assessed the hits from the biochemical screening in a cell-based SARS-CoV-2 pseudotyped particle entry assay. Of the six molecules advanced for further studies, two are approved drugs in Japan (camostat and nafamostat), two have entered clinical trials ( $\mathrm{PCl}-27483$ and otamixaban), while the other two molecules are peptidomimetic inhibitors of TMPRSS2 taken from the literature that have not advanced into clinical trials (compounds 92 and 114). This work demonstrates a suite of assays for the discovery and development of new inhibitors of TMPRSS2. 


\section{Introduction}

The severe acute respiratory syndrome-related coronavirus 2 (SARS-CoV-2) pandemic has driven the need for development of effective therapeutics to be used as prophylactics and as a treatment for infected patients. At the outset of the pandemic, there were no approved therapeutics for treating any coronaviruses, which led to the initiation of several human clinical trials on existing clinical candidates and approved drugs. Drug repurposing allows for drugs to be fast-tracked to the clinic for trials addressing a different disease than it was originally intended. An initial step in drug repurposing is the development of in vitro assays capable of generating efficacy data on the candidates for drug repurposing, which is critical for either supporting or denying their movement into human clinical trials. An example of this was remdesivir (GS-5734, Gilead Sciences Inc.) that had previously been in clinical trials for treating the Ebola virus but was repurposed as a SARS-CoV-2 treatment following its demonstration as a viral polymerase inhibitor within an in vitro experiment using live SARS-CoV-2 virus, leading to FDA approval. ${ }^{1,2}$

Host cell targets have also received significant attention, partly because pharmacologic modulation should be invariable against viral variants/mutants. ${ }^{3}$ Host antiviral targets are often human proteins whose function has been co-opted and are essential to the viral replication cycle. ${ }^{4}$ Transmembrane protease serine 2 (TMPRSS2) is a human protein within the family of type-II transmembrane serine proteases (TTSP) expressed in epithelial cells of the human lungs, airways, and gastrointestinal tracts. ${ }^{5,6}$ TMPRSS2 has become a therapeutic target due to its role in SARS-CoV-2 infection of a cell, and the existence of approved therapeutics able to inhibit its protease activity and be assessed for drug repurposing. ${ }^{7}$ A mechanism for SARS-CoV-2 entry includes binding of its surface glycoprotein spike (S) with the human cell-surface receptor angiotensin-converting enzyme 2 (ACE2), followed by cleavage at 
two sequences on the spike protein that can be done by human cell surface proteases, such as TMPRSS2, which causes a conformational change in spike resulting in membrane fusion and release of the viral RNA into the host cell. ${ }^{8-10}$ TMPRSS2 is considered the primary protease within the lung due to it having the highest co-expression with ACE2. ${ }^{5}$

We have reported an in vitro enzymatic assay using recombinant TMPRSS2 and a fluorogenic substrate, BOC-QAR-AMC, to demonstrate whether drug repurposing candidates, such as camostat and nafamostat, could inhibit the protease activity. ${ }^{11}$ Additionally, the enzymatic assay was used to evaluate hits identified from virtual screens. ${ }^{12,13}$ Since our initial report on the development of an in vitro assay using recombinant TMPRSS2, several other in vitro assays have been developed. A cell-based in vitro assay using the fluorogenic substrate, BOC-QAR-AMC, in HEK293T cells overexpressing TMPRSS2 allows for quantification of proteolytic activity of TMPRSS2 and assessment of inhibitors within the cellular context compared to recombinant protein. ${ }^{14}$ Fluorescence resonance energy transfer (FRET)-based peptides mimicking the spike cleavage sites (S1/S2 and S2') with recombinant TMPRSS2 demonstrated the capability of TMPRSS2 to cleave at both relevant spike cleavage sites. ${ }^{15} \mathrm{~A}$ split-luciferase in vitro assay using an engineered full-length human TMPRSS2 expressing a C-terminal HiBiT tag reported on both plasma membrane-associated and intracellular TMPRSS2 expression levels and demonstrated that homoharringtonine and halofuginone reduced total TMPRSS2 expression. ${ }^{16}$ Cell lines expressing TMPRSS2 (either endogenously or through transfection) have been used with pseudotyped particles or live virus assays to demonstrate the importance of TMPRSS2 in SARS-CoV-2 infection, and assess therapeutic candidates. ${ }^{17,18}$ Altogether, assays on TMPRSS2 have been extensively used to assess therapeutic effectiveness.

Here, we report the development of a mass spectrometry-based detection assay using recombinant TMPRSS2 and an unlabeled peptide substrate that mimics the SARS-CoV-2 spike cleavage site, S2'. We demonstrate the suitability of the assay in 384-well plates, and its utility as an orthogonal assay capable 
of detecting false positive hits from the fluorogenic substrate assay. Additionally, the assay showed the ability of TMPRSS2 to cleave the spike cleavage site mimicked by the peptide, which agrees with results derived from use of FRET peptides within another study. ${ }^{15}$ Furthermore, we report the screening of inhibition of TMPRSS2 from several drug repurposing candidates within 6030 molecules in the NCATS drug libraries and an in-house compiled protease inhibitor library by using the fluorogenic peptide assay. Hits were further tested in the orthogonal mass spectrometry-based detection assay and a pseudotyped particle cell entry assay. The particles were pseudotyped with either the spike protein of the 'wildtype' (WA1 + D614G) or Delta strain (B.1.617.2), in Calu-3 human non-small cell lung cancer cells to demonstrate inhibition and cellular efficacy. Altogether, six molecules demonstrated activity in the biochemical and cell-based assays while remaining inactive in the counter assays. Two of these molecules, camostat and nafamostat, were the most potent inhibitors of TMPRSS2 and are both in human clinical trials as an antiviral against COVID-19. ${ }^{19,} 20$ Another two drug repurposing candidates, otamixaban and $\mathrm{PCl}-27483$, demonstrated activity but have not entered human clinical trials for treatment of COVID-19. The final two molecules were identified from the literature as peptidomimetic inhibitors of TMPRSS2. ${ }^{21}$ Several other molecules were found to be weaker inhibitors. This work demonstrates an assay toolset for the discovery and development of new TMPRSS2 inhibitors. 


\section{Results}

\section{Assay design}

Following our initial report on the development of a biochemical assay capable of monitoring TMPRSS2 activity and inhibition, we set out to conduct a drug repurposing screen. ${ }^{11}$ To briefly summarize the biochemical assay, yeast-expressed recombinant TMPRSS2 (aa 106-492, CUSAbio) was used along with a fluorogenic peptide substrate, BOC-QAR-AMC to monitor enzymatic activity via release of the caged 7amino-4-methylcourmarin (AMC) fluorophore from the peptide at an emission wavelength of $440 \mathrm{~nm}$ (Figure 1). Buffer conditions were tested and optimized to include: $50 \mathrm{mM}$ Tris $\mathrm{pH} 8,150 \mathrm{mM} \mathrm{NaCl}$ and 0.01\% Tween20. Using the peptide substrate at $10 \mu \mathrm{M}$, near its $\mathrm{K}_{\mathrm{m}}$ of $33 \mu \mathrm{M}$, and TMPRSS2 at $175 \mathrm{nM}$, we achieved a signal-to-background (S:B) and $Z^{\prime}$ of 3.2 and 0.86 , respectively in a 1536-well plate. This demonstrated appropriate performance for this assay to be useful for quantitative high-throughput screening (qHTS). ${ }^{22}$

\section{Drug repurposing qHTS of annotated small molecule libraries}

Three compound libraries were selected for qHTS that are ideal for drug repurposing efforts: the NCATS Pharmaceutical Collection (NPC) contains all approved agents from USA, Europe, and Japan as of 2017 along with additional clinical candidates (2,678 compounds), the Mechanism Interrogation Plate (MIPE) is an oncology-focused library with a combination of approved and clinical agents (2,480 compounds), and an in-house compiled protease inhibitor library (PIL, 872 compounds) to screen against TMPRSS2, a total of 6,030 compounds (qHTS assay protocol shown in Table 1). Along with the potential for repurposing, the compounds in these libraries are annotated for published mechanisms of action. Each 1536-well plate contained 32 positive and 64 negative control wells to monitor assay performance. When screening the NPC library, the average plate Z' was 0.76 with an average S:B of 2.39 (Figure 2A). The MIPE collection had an average plate $Z^{\prime}$ of 0.72 with an average S:B of 2.33 (Figure 2B). The PIL collection had an average plate $Z^{\prime}$ of 0.87 with an average $S: B$ of 4.86 (Figure $2 \mathrm{C}$ ). 


\section{Hit identification}

The primary screen for NPC and MIPE were executed using compound concentrations of $40 \mu \mathrm{M}, 8 \mu \mathrm{M}$

and $1.6 \mu \mathrm{M}$, and hit selection criteria was set for those having a maximum response of $\geq-30 \%$ inhibition. A total of 14 compounds ( $0.5 \%$ hit rate) were identified as hits from the NPC library and 14 compounds (0.6\% hit rate) were identified from the MIPE library. The primary screen for the PIL used compound concentrations of $40 \mu \mathrm{M}, 10 \mu \mathrm{M}, 2.5 \mu \mathrm{M}$, and $0.625 \mu \mathrm{M}$. Using the same hit selection criterion ( $\max$ response $\geq-30 \%$ inhibition) yielded 37 active compounds ( $4.2 \%$ hit rate). Thus, from a screen of 6,030 compounds a total of 52 unique hits were identified, as there was redundancy from multiple hits presented between the libraries. Within the primary screen, 18,962 data points were generated. All qHTS data from the NPC and MIPE primary screens, and detailed protocol sheets, are available for download at the OpenData Portal website (https://opendata.ncats.nih.gov/covid19/). ${ }^{23}$

\section{Hit confirmation}

To confirm the hits identified from primary screening of the compound libraries, we tested each hit compound in triplicate dose-response in the primary fluorogenic biochemical assay using fresh stock. Compounds were plated in triplicate, 11-point, 1:3 dilution series using an ECHO 655 (LabCyte) acoustic dispenser. Of the 52 hits identified from the primary screening, 28 hits retained a max response inhibition of $\geq-30 \%$ when tested in triplicate dose-response. Next, the 28 hits were tested in a fluorescent counterassay, to detect false-positive hit compounds capable of quenching AMC fluorescence and mimicking inhibition, that involved the addition of compounds in dose-response to a buffer containing $1 \mu \mathrm{M}$ AMC that approximates the estimated 10\% enzymatic cleavage in the fluorogenic assay (i.e., starting concentration of substrate is $10 \mu \mathrm{M}$, counterassay protocol shown in Table 2). The counter-assay identified one compound (tannic acid) capable of quenching the AMC fluorescent signal $\sim 30 \%$. Altogether, 27 compounds confirmed as inhibitors of TMPRSS2, which had $\geq-$ $30 \%$ inhibition and $\leq-10 \%$ fluorescence quenching (Supplementary Table 1). 


\section{Orthogonal mass spectrometry assay development}

We next developed a biochemical assay using mass spectrometry and an unlabeled peptide substrate, with a peptide sequence from the S2' site on the spike protein of SARS-CoV-2 (Figure 3A). Directly measuring an unlabeled peptide product, rather than a fluorescent product, removes the possibility of false positives from compound fluorescence interference. ${ }^{24,25}$ The unlabeled peptide substrate sequence selected was Cbz-SKPSKRSFIED (scissile amide bond bolded), that yields cleavage products of Cbz-SKPSKR and SFIED by TMPRSS2 (Figure 3B). As the unlabeled peptide substrate sequence is derived from the SARS-CoV-2 spike protein TMPRSS2 cleavage site on the virus, it may be considered a more physiologically relevant approach to identifying and assessing TMPRSS2 inhibitors.

Linearity of detection for the spiked internal standard peptide (Cbz-SK- $\left\{{ }^{13} \mathrm{C}_{5}{ }^{15} \mathrm{~N}\right.$ Pro\}-SKR), which is the isotopically labeled version of the product peptide (Cbz-SKPSKR), was demonstrated through generation of a standard curve using concentrations from $1 \mathrm{nM}$ to $2000 \mathrm{nM}$. To determine the $\mathrm{K}_{\mathrm{m}}$ of CbzSKPSKRSFIED to guide assay substrate concentration, ${ }^{26}$ the TMPRSS2 concentration was held constant at $400 \mathrm{nM}$ while substrate concentration varied from $2.5 \mu \mathrm{M}$ to $400 \mu \mathrm{M}$. The enzymatic reaction was quenched by adding a quench solution ( $90: 10$ acetonitrile:water $+0.1 \%$ formic acid $+100 \mathrm{nM}$ of the internal standard (Cbz-SK- $\left\{{ }^{13} \mathrm{C}_{5}{ }^{15} \mathrm{~N}\right.$ Pro\}-SKR), 1:1). The fragment peptides detected were the desired product (Cbz-SKPSKR, m/z 418.8/702.4) and the internal standard peptide ( $\mathrm{m} / \mathrm{z}$ 421.64/708.24), assay protocol shown in Table 3. Quantification of product formation was determined by observing the integrated area of the mass peak ratio between the desired product and internal standard. From the substrate titration experiment, the initial velocity was determined at each substrate concentration by plotting the amount of product formed against time (Figure $3 \mathrm{C}$ ). Initial velocities were plotted against substrate concentrations (Figure 3D), indicating that the $\mathrm{K}_{m}$ was indeterminate as it yielded a value of $2320 \mu \mathrm{M}$, which is higher than the maximum substrate concentration in the assay. Due to the 
indeterminate $\mathrm{K}_{\mathrm{m}}$, the assay conditions were set using an identical concentration of peptide substrate as the fluorogenic assay $(10 \mu \mathrm{M})$. Under these conditions, the $\mathrm{IC}_{50}$ obtained from the mass spectrometry detection assay for camostat and gabexate were $6.6 \mathrm{nM}(95 \% \mathrm{Cl}: 5.4,8.2)$ and $119 \mathrm{nM}(95 \% \mathrm{Cl}: 76.8$, 181.3), respectively, which is statistically equivalent to that obtained from the fluorogenic assay, $6.2 \mathrm{nM}$ (95\% Cl: 5.5, 7.0) and $130 \mathrm{nM}(95 \% \mathrm{Cl}: 107.2,147.5)$ (Figure 3E,F). Positive and negative control conditions were assessed in a 384-well plate format to demonstrate appropriate performance, which showed a S:B and $Z^{\prime}$ of 7.37 and 0.71 , respectively (Figure $3 G$ ).

The 27 confirmed hits from the fluorogenic assay were tested in the mass spectrometry detection assay. One qHTS hit that failed to inhibit in the mass spectrometry detection assay was 7-hydroxycoumarin, a fluorescent molecule similar to 7-amino-4-methylcoumarin that is released upon cleavage of the fluorogenic substrate. Based on the fluorogenic assay, 7-hydroxycoumarin showed nearly full inhibition of TMPRSS2 at $40 \mu \mathrm{M}$; yet there was no inhibition detected within the mass spectrometry detection assay (Figure 3H). The cause for this discrepancy likely comes from 7-hydroxycoumarin being fluorescent; thereby, the endpoint fluorescent detection is overwhelmed by the amount of inhibitor fluorescence compared to the added cleaved product fluorescence. Since there is no increased fluorescence from the cleaved product at T60 (when quench solution is added) compared to T0, it appears that TMPRSS2 was fully inhibited with no cleaved product formation. This is an example of an assay interference false positive due to compound auto-fluorescence. ${ }^{24}$ The benefits of the mass spectrometry detection assay are twofold: 1 ) lower number of interference compounds identified, as demonstrated by 7-hydroxycoumarin and 2) capability of using a more physiologically relevant substrate that is unlabeled. Overall, 21 of the 27 compounds assessed for inhibition of TMPRSS2 showed activity. Unlike the assay interference compound, 7-hydroxycoumarin, the other five compounds that did not inhibit TMPRSS2 within the mass spectrometry detection assay was likely due to their weak activity within the fluorogenic assay. 


\section{SARS-CoV-2-S Pseudotyped Particle Entry Assays.}

Finally, we demonstrated the effectiveness of these small molecules at preventing TMPRSS2-dependent viral entry into cells using a SARS-CoV-2 spike pseudotyped particle (PP) entry assay performed with the human airway epithelium cell line Calu-3, as previously described (Figure 4A,B). ${ }^{18}$ In addition to being the airway epithelium cell model, Calu-3 cells rely on serine proteases, like TMPRSS2, for viral entry when compared to other cell line models, which makes this cell line ideal for testing inhibitors of TMPRSS2. ${ }^{17}$ Two different pseudotyped particles with spike from different variants were used to assess TMPRSS2 inhibitors: one containing the Delta variant (B.1.617.2) spike protein that bears the mutations T19R, G142D, del156-157, R158G, L452R, T478K, D614G, P681R, D950N, and one containing the WA1 + D614G spike sequence. Notably, the Delta variant carries a P681R mutation in the S1/S2 cut site of the spike protein that may affect the cleavage activity by TMPRSS2; however, there are no mutations within the S2' cut site. It's unclear how the various mutations may affect the cleavage activity by TMPRSS2. A cytotoxicity counter assay was performed to assess whether hits were cytotoxic towards Calu-3 cells, which would produce a false-positive indicator of activity in the PP assay.

Compounds having confirmed inhibition of TMPRSS2 in both biochemical assays and in the cellular assay are listed in Table 4. Of the three most potent inhibitors of TMPRSS2 from the screening, camostat and nafamostat also demonstrated the greatest potency within the PP entry assay against the Delta pseudotyped particle with IC 50 of $59 \mathrm{nM}$ and $1.4 \mathrm{nM}$, respectively (Figure 4C,D). However, gabexate was inactive at inhibiting viral particle entry (Figure 4E). This result is in agreement with other studies reporting gabexate is inactive in cell-based assays testing TMPRSS2 inhibition. ${ }^{27,28}$ Notably, bortezomib appeared to demonstrate a highly potent inhibition of viral entry $\left(I C_{50}<50 \mathrm{nM}\right)$; however, the cytotoxicity counter-assay revealed it was due to high cytotoxicity of the Calu-3 cells, which again demonstrates the importance and necessity of appropriate counterassays in designing an assay pipeline 
(Figure 4F). Additional evidence that 7-hydroxycoumarin is a false-positive identified from the

fluorogenic assay is its lack of activity within the cell-based assay evaluating viral entry inhibition

(Supplementary Table 1). The rest of the HTS hits had weak to no inhibition in the cell-based PP assay,

most likely due to their already weak activity against TMPRSS2 from the biochemical assay. Notably, potency of the molecules was not significantly shifted between the two different types of pseudotyped particles from the two variants. This demonstrates the validity of drugging host targets such as TMPRSS2 to avoid viral escape of the antiviral therapy.

\section{Discussion}

Here we developed the first reported mass spectrometry-based detection assay for TMPRSS2 activity, and demonstrate a TMPRSS2 early drug discovery pipeline. To demonstrate proof-of-concept, we performed a HTS using our drug repurposing libraries.

The advantages to developing a mass spectrometry-based detection assay are twofold: 1) the unlabeled substrate can be more physiologically relevant leading to higher quality inhibitors being identified, 2) the unlabeled substrate avoids identification of a false positive that may arise in a fluorescence-based detection assay from inhibitor fluorescent quenching or compound fluorescence. ${ }^{24}$ For example, 7hydroxycoumarin was identified as a hit within the fluorogenic assay. However, at the highest concentration tested of $40 \mu \mathrm{M}$, this molecule increases fluorescence to $1300 \mathrm{x}$ above the baseline level of fluorescence coming from the fluorogenic peptide substrate. Consequently, there is no increased fluorescence upon TMPRSS2 cleavage of the AMC from the fluorogenic peptide substrate; therefore, it instead appears that the enzyme was fully inhibited. The 7-hydroxycoumarin molecule did not show inhibition of TMPRSS2 in the mass spectrometry-based detection assay nor any inhibition of pseudotyped particle entry into Calu-3 cells. 
Drug repurposing screening on in vitro assays yields initial proof-of-concept data that can be used to fast-track a drug to the clinic for trials addressing a different disease than it was originally intended. Our primary drug repurposing screen used recombinant TMPRSS2 with a fluorogenic peptide substrate with fluorescence detection. The screen included compounds from three in-house libraries totaling 6,030 compounds with many being drug repurposing candidates. Each compound was tested at multiple concentrations leading to generation of 18,962 data points. The primary screen yielded 52 hits. Upon assessing each of these compounds in an 11-point dose-response and in a fluorescence counter assay, only 27 compounds remained as confirmed hits. Each of these compounds were tested in dose-response for inhibition of TMPRSS2 in the mass spectrometry detection assay and in dose-response for inhibition of pseudotyped particle entry into Calu-3 cells.

Altogether, six compounds demonstrated inhibition of TMPRSS2 in biochemical and cellular assays. Those six compounds include two approved drugs (nafamostat and camostat, both approved in Japan to treat pancreatitis), two clinical candidates ( $\mathrm{PCl}-27483$ and otamixaban) and two literature compounds (compound 92 and compound 114). ${ }^{21}$

$\mathrm{PCl}-27483$ was originally developed as a highly potent and selective inhibitor of the serine protease Factor VIla (FVIla) when in complex with tissue factor (TF) that has a normal physiological role in the initiation of the blood clotting cascade in response to an injured blood vessel wall. ${ }^{29}$ However, TF has been shown to be overexpressed in numerous primary tumors and is associated with tumor progression and worsened survival in cancer patients. This complex may contribute to tumor invasiveness by promoting cell migration and angiogenesis. ${ }^{30}$ Consequently, $\mathrm{PCl}-27483$ entered clinical trials for patients with advanced pancreatic cancer in combination with gemcitabine. This trial has completed and though the combination was well tolerated, there was no demonstrated efficacy. ${ }^{31} \mathrm{PCl}-27483$ was first identified as a drug repurposing candidate as an inhibitor of TMPRSS2 by using a structure-based phylogenetic computational tool called 3DPhyloFold to identify structurally similar serine proteases, 
such as FVIla, with known inhibitors that docked well to the TMPRSS2 structural model. ${ }^{32}$ Later, PCI27483 was identified and confirmed to be an inhibitor of TMPRSS2 by NCATS scientists using a structural modeling and binding-site analysis of TMPRSS2 followed by a structure-based virtual screening and molecular docking approach. ${ }^{12}$ Though it has been demonstrated within in vitro studies as an inhibitor of TMPRSS2, it has yet to enter clinical trials as an antiviral treatment for COVID-19. The other clinical candidate, otamixaban, is an inhibitor of factor Xa ( $\mathrm{fXa})$, a critical serine protease in the blood coagulation cascade that catalyzes the conversion of prothrombin to thrombin. ${ }^{33,34}$ Otamixaban entered clinical trials as an anticoagulant for patients with non-ST-segment elevation acute coronary syndromes (NSTE-ACS) against a control arm using unfractionated heparin plus eptifibatide. Otamixaban was shown to be safe but lack efficacy relative to the control arm. ${ }^{35}$ Otamixaban was first identified as a drug repurposing candidate as an inhibitor of TMPRSS2 within a virtual screen. ${ }^{36}$ Corroborating data came from the Noe lab and our group that included computational, biochemical and cellular data to demonstrate its inhibition of TMPRSS2. ${ }^{12,13}$ It has yet to enter clinical trials as an antiviral treatment for COVID-19.

The two literature compounds, 92 and 114, have sulfonylated 3-amindinophenylalanylamide core structures that were among the initial synthetic inhibitors of TMPRSS2. ${ }^{21}$ The Steinmetzer lab, developed a fluorescence based assay using a fluorogenic peptide substrate used with recombinant TMPRSS2 to identify 92 and $\mathbf{1 1 4}$ as potent inhibitors with a $K_{i}$ of $0.9 \mathrm{nM}$ and $5 \mathrm{nM}$, respectively. Both were shown to be not cytotoxic within Calu-3 cells. Additionally, $\mathbf{9 2}$ significantly reduced the replication of H1N1 and H3N2 influenza virus strains in Calu-3 cells. However, no further studies had been done with respect to SARS-CoV-2 with these compounds. We demonstrate inhibition of TMPRSS2 with an $\mathrm{IC}_{50}$ of $\sim 300 \mathrm{nM}$ for both compounds and blocking of entry into Calu-3 cells using pseudotyped particles with SARS-CoV-2 spike protein with an $\mathrm{IC}_{50}$ of $4 \mu \mathrm{M}$ and $15 \mu \mathrm{M}$ for 92 and 114, respectively. 


\section{Methods}

Reagents. Recombinant Human TMPRSS2 protein expressed from yeast (human TMPRSS2 residues 106-492, N-terminal 6x His-tag) (cat.\# CSB-YP023924HU) was acquired from Cusabio. The fluorogenic peptide substrate, Boc-QAR-AMC. HCl was obtained from Bachem (cat.\# I-1550). The unlabeled peptide substrate, Cbz-SKPSKRSFIED was custom ordered from LifeTein.

Fluorogenic Peptide Screening Protocol 1536-Well Plate. To a 1536-well black plate was added BocQAR-AMC substrate $(2.5 \mathrm{mM}, 20 \mathrm{~nL}, 250 \mathrm{x})$ and inhibitor (20 nL, 250x) using an ECHO 655 acoustic dispenser (LabCyte). To that was dispensed TMPRSS2 (reconstituted in 50\% glycerol at $8.75 \mu \mathrm{M}, 50 \mathrm{x}$ ) in assay buffer ( $50 \mathrm{mM}$ Tris $\mathrm{pH} 8,150 \mathrm{mM} \mathrm{NaCl}, 0.01 \%$ Tween20) using a BioRAPTR (Beckman Coulter) to give a total reaction volume of $5 \mu \mathrm{L}$. Following $1 \mathrm{~h}$ of incubation at RT, detection was done using the PHERAstar with $340 \mathrm{~nm}$ excitation and $440 \mathrm{~nm}$ emission (Table 1).

Fluorescence Counter Assay 1536-Well Plate. To a 1536-well black plate was added 7-amino-4methylcoumarin $(0.25 \mathrm{mM}, 20 \mathrm{~nL}, 250 \mathrm{x})$ and inhibitor ( $20 \mathrm{~nL}, 250 \mathrm{x})$ to columns 5-48 using an ECHO 655 acoustic dispenser (LabCyte). To the control columns 1-2 was added 7-amino-4-methylcoumarin (0.25 $\mathrm{mM}, 20 \mathrm{~nL}, 250 \mathrm{x})$ and DMSO (20 nL), and to the control columns 3-4 was added 7-amino-4methylcoumarin $(0.025 \mathrm{mM}, 20 \mathrm{~nL}, 250 \mathrm{x})$ and DMSO $(20 \mathrm{~nL})$. Assay buffer (50 mM Tris pH 8, $150 \mathrm{mM}$ $\mathrm{NaCl}, 0.01 \%$ Tween 20 ) was added to the full plate to give a total reaction volume of $5 \mu \mathrm{L}$. Detection was done using the PHERAstar with $340 \mathrm{~nm}$ excitation and $440 \mathrm{~nm}$ emission. Fluorescence was normalized relative to a negative control containing 7-amino-4-methylcoumarin at $0.1 \mu \mathrm{M}(-100 \%$ activity, low fluorescence) and a positive control containing 7-amino-4-methylcoumarin at $1 \mu \mathrm{M}$ (0\% activity, high fluorescence). An inhibitor causing fluorescence quenching would be identified as having a concentration-dependent decrease on AMC fluorescence resulting in a $<0 \%$ activity (Table 2). 
Mass Spectrometry-based Assay 384-well plate. To a 384-well plate (Greiner 781201) was added CbzSKPSKRSFIED substrate (2.5 mM, $200 \mathrm{~nL}, 250 x)$ and inhibitor (200 nL, 250x) using an ECHO 655 acoustic dispenser (LabCyte). To that was dispensed TMPRSS2 (reconstituted in 50\% glycerol at $8.75 \mu \mathrm{M}, 22 \mathrm{x}$ ) in assay buffer (50 mM Tris $\mathrm{pH} 8,150 \mathrm{mM} \mathrm{NaCl}$ ) using a BioRAPTR (Beckman Coulter) to give a total reaction volume of $50 \mu \mathrm{L}$. Following $1 \mathrm{~h}$ of incubation at $\mathrm{RT}$, the reaction was quenched by adding 90:10 $\mathrm{ACN}: \mathrm{H}_{2} \mathrm{O}+0.1 \%$ formic acid $+100 \mathrm{nM}$ of internal standard (Cbz-SK- $\left\{{ }^{13} \mathrm{C}_{5}{ }^{15} \mathrm{~N}\right.$ Pro $\left.\}-\mathrm{SKR}, 50 \mu \mathrm{L}\right)$ to give a total volume of $100 \mu \mathrm{L}$. Samples were further diluted 10 -fold using $20 \mathrm{mM}$ ammonium formate $+0.1 \%$ formic acid prior to injection into a SciEx6500, and the data were analyzed using Analyst Software. An LS-1 autosampler (Sound Analytics, Niantic, CT) injected samples to the $2 \times 20 \mathrm{~mm}$ Halo C18 (Mac-Mod) column for LC separation. The LC buffers were A: $0.1 \%$ difluoroacetic acid in water and B: acetonitrile, and a gradient elution was used that went from $5 \%$ Buffer B to $90 \%$ Buffer B in 0.5 min with a flow rate of $0.70 \mathrm{~mL} / \mathrm{min}$. The cleavage fragment (Cbz-SKPSKR): $418.8 / 702.4 \mathrm{~m} / \mathrm{z}$ was quantified to asses TMPRSS2 activity (Table 3).

Data Process and Analysis. To determine compound activity in the assay, the concentration-response data for each sample was plotted and modeled by a four-parameter logistic fit yielding $\mathrm{IC}_{50}$ and maximal response values. Raw plate reads for each titration point were first normalized relative to a positive control containing nafamostat at $1 \mu \mathrm{M}$ ( $0 \%$ activity, full inhibition) and a negative control containing DMSO-only wells (100\% activity, basal activity). Data normalization, visualization, and curve fitting were performed using Prism (GraphPad, San Diego, CA).

SARS-CoV-2-S Pseudotyped Particle Entry Assays. A SARS-CoV-2 Spike pseudotyped particle (PP) entry assay was performed as previously described (Chen et. al.) In short, 40,000 cells/well Calu3 cells (catalog HTB-55, ATCC) were seeded in white, solid bottom 96-well microplates (Greiner BioOne) in $100 \mu \mathrm{L} /$ well media and incubated at $37^{\circ} \mathrm{C}$ with $5 \% \mathrm{CO}_{2}$ overnight $(\sim 16 \mathrm{~h})$. Then, the supernatant was removed, and compounds were added as $50 \mu \mathrm{L} /$ well, $2 \mathrm{X}$ solutions in media. Cells were incubated with compounds for 
$1 \mathrm{~h}$ at $37^{\circ} \mathrm{C}$ with $5 \% \mathrm{CO} 2$, before $50 \mu \mathrm{L} /$ well of SARS-CoV-2-S pseudotyped particles (PP) was added. We used the PP pseudotyped SARS-CoV-2 spike from the Delta variant B.1.617.2 (catalog 21H13, Codex Biosolutions) with a C-terminal 19 amino acid deletion using the murine leukemia virus system as previously described (Millet et. al.). The plates were then spinoculated by centrifugation at $1500 \mathrm{rpm}$ (453g) for $45 \mathrm{~min}$ and incubated for $48 \mathrm{~h}$ at $37^{\circ} \mathrm{C}$ with $5 \% \mathrm{CO}_{2}$ to allow the cell entry of PP and the expression of the luciferase reporter. After the incubation, the supernatant was removed, and $20 \mu \mathrm{L} /$ well of the Bright-Glo Luciferase detection reagent (catalog E2620, Promega) was added to assay plates and incubated for $5 \mathrm{~min}$ at room temperature. The luminescence signal was measured using a PHERAStar plate reader (BMG Labtech). The data were normalized with wells containing SARS-CoV-2-S PPs as 0\% and wells containing control bald PP as $-100 \%$. A cytotoxicity counter screen was performed using the same protocol without the addition of PP, with an adenosine triphosphate (ATP) content assay kit (catalog 6016949, Promega). 
Table 1. Detailed TMPRSS2 fluorogenic biochemical assay protocol for qHTS.

\begin{tabular}{|c|c|c|}
\hline Step \# & Process & Notes \\
\hline 1 & $\begin{array}{l}20 \mathrm{~nL} \text { of peptide substrate } \\
\text { dispensed into } 1536 \text {-well plates. }\end{array}$ & $\begin{array}{l}\text { Peptide ( } 250 x \text {, dissolved in DMSO) was } \\
\text { dispensed using an ECHO } 655 \text { acoustic } \\
\text { dispenser (LabCyte) into a Corning 1536-well } \\
\text { plate (Cat \#3724). }\end{array}$ \\
\hline 2 & $\begin{array}{l}\text { Compounds and controls ( } 20 \mathrm{~nL}) \\
\text { were pre-spotted into } 1536 \text {-well } \\
\text { plates. }\end{array}$ & $\begin{array}{l}\text { Inhibitor ( } 250 \mathrm{x} \text { ) or vehicle control (DMSO) } \\
\text { was dispensed using an ECHO } 655 \text { acoustic } \\
\text { dispenser (LabCyte). Compounds in dose- } \\
\text { response were dispensed to columns 5-48 } \\
\text { and controls dispensed into columns 1-4. }\end{array}$ \\
\hline 3 & $\begin{array}{l}\text { TMPRSS2 diluted in assay buffer } \\
\text { dispensed into } 1536 \text {-well plates. }\end{array}$ & $\begin{array}{l}\text { TMPRSS2 (reconstituted in } 50 \% \text { glycerol at } \\
8.75 \mu \mathrm{M}, 50 \mathrm{x} \text { ) in assay buffer ( } 50 \mathrm{mM} \text { Tris } \mathrm{pH} \\
8,150 \mathrm{mM} \mathrm{NaCl}, 0.01 \% \text { Tween } 20 \text { ) was } \\
\text { dispensed using a BioRAPTR (Beckman } \\
\text { Coulter). Total reaction volume of } 5 \mu \mathrm{L} \text {. }\end{array}$ \\
\hline 4 & Incubated at RT for $1 \mathrm{hr}$ & $\begin{array}{l}\text { Final assay conditions were } 10 \mu \mathrm{M} \text { peptide } \\
\text { and } 0.175 \mu \mathrm{M} \text { TMPRSS } 2 \text { in assay buffer ( } 50 \\
\mathrm{mM} \text { Tris- } \mathrm{HCl} \mathrm{pH} 8,150 \mathrm{mM} \mathrm{NaCl}, 0.01 \% \\
\text { Tween20) }\end{array}$ \\
\hline 5 & $\begin{array}{l}\text { Read on PHERAstar FSX (BMG } \\
\text { Labtech) }\end{array}$ & $\begin{array}{l}\text { Fastest read settings, Fluorescence Intensity } \\
\text { module: } 340 \mathrm{~nm} \text { excitation, } 440 \mathrm{~nm} \text { emission } \\
\text { (Cat \# 1601A2, BMG Labtech) }\end{array}$ \\
\hline
\end{tabular}


Table 2. Detailed fluorescence counterassay protocol for qHTS hits.

\begin{tabular}{|c|c|c|}
\hline Step \# & Process & Notes \\
\hline 1 & $\begin{array}{l}20 \mathrm{~nL} \text { of } 7 \text {-amino-4- } \\
\text { methylcoumarin dispensed into } \\
1536 \text {-well plates. }\end{array}$ & $\begin{array}{l}\text { AMC ( } 250 x \text {, dissolved in DMSO) was } \\
\text { dispensed using an ECHO } 655 \text { acoustic } \\
\text { dispenser (LabCyte) into a Corning 1536-well } \\
\text { plate (Cat \#3724). }\end{array}$ \\
\hline 2 & $\begin{array}{l}\text { Compounds and controls ( } 20 \mathrm{~nL}) \\
\text { were pre-spotted into } 1536 \text {-well } \\
\text { plates. }\end{array}$ & $\begin{array}{l}\text { Inhibitor ( } 250 x \text { ) or vehicle control (DMSO) } \\
\text { was dispensed using an ECHO } 655 \text { acoustic } \\
\text { dispenser (LabCyte). Compounds in dose- } \\
\text { response were dispensed to columns 5-48 } \\
\text { and controls dispensed into columns 1-4. }\end{array}$ \\
\hline 3 & $\begin{array}{l}\text { Assay buffer dispensed into } \\
\text { 1536-well plates. }\end{array}$ & $\begin{array}{l}\text { Assay buffer ( } 50 \mathrm{mM} \text { Tris } \mathrm{pH} 8,150 \mathrm{mM} \mathrm{NaCl} \text {, } \\
0.01 \% \text { Tween } 20 \text { ) was dispensed using a } \\
\text { BioRAPTR (Beckman Coulter). Total reaction } \\
\text { volume of } 5 \mu \mathrm{L} \text {. }\end{array}$ \\
\hline 4 & Incubated at RT for $5 \mathrm{~min}$ & $\begin{array}{l}\text { Final assay conditions were } 1 \mu \mathrm{M} \text { AMC with } \\
\text { inhibitor or control (DMSO) in assay buffer } \\
\text { ( } 50 \mathrm{mM} \text { Tris- } \mathrm{HCl} \mathrm{pH} 8,150 \mathrm{mM} \mathrm{NaCl}, 0.01 \% \\
\text { Tween20). Columns } 3 \text { and } 4 \text { had } 0.1 \mu \mathrm{M} \text { AMC } \\
\text { with control (DMOS) in assay buffer. }\end{array}$ \\
\hline 5 & $\begin{array}{l}\text { Read on PHERAstar FSX (BMG } \\
\text { Labtech) }\end{array}$ & $\begin{array}{l}\text { Fastest read settings, Fluorescence Intensity } \\
\text { module: } 340 \mathrm{~nm} \text { excitation, } 440 \mathrm{~nm} \text { emission } \\
\text { (Cat \# 1601A2, BMG Labtech) }\end{array}$ \\
\hline
\end{tabular}


Table 3. Detailed TMPRSS2 mass spectrometry detection biochemical assay.

\begin{tabular}{|c|c|c|}
\hline Step \# & Process & Notes \\
\hline 1 & $\begin{array}{l}200 \mathrm{~nL} \text { of peptide substrate } \\
\text { dispensed into } 384 \text {-well plates. }\end{array}$ & $\begin{array}{l}\text { Peptide (Cbz-SKPSKRSFIED, 250x, dissolved in } \\
\text { DMSO) was dispensed using an ECHO } 655 \\
\text { acoustic dispenser (LabCyte) into a Greiner } \\
\text { 384-well plate (Cat \#781201). }\end{array}$ \\
\hline 2 & $\begin{array}{l}\text { Compounds and controls ( } 200 \\
\mathrm{~nL}) \text { were pre-spotted into } 384- \\
\text { well plates. }\end{array}$ & $\begin{array}{l}\text { Inhibitor (250x) or vehicle control (DMSO) } \\
\text { was dispensed using an ECHO } 655 \text { acoustic } \\
\text { dispenser (LabCyte). Compounds in dose- } \\
\text { response were dispensed to columns 5-24 } \\
\text { and controls dispensed into columns 1-4. }\end{array}$ \\
\hline 3 & $\begin{array}{l}\text { TMPRSS2 diluted in assay buffer } \\
\text { dispensed into } 384 \text {-well plates. }\end{array}$ & $\begin{array}{l}\text { TMPRSS2 (reconstituted in } 50 \% \text { glycerol at } \\
8.75 \mu \mathrm{M}, 22 \mathrm{x} \text { ) in assay buffer ( } 50 \mathrm{mM} \text { Tris } \mathrm{pH} \\
8,150 \mathrm{mM} \mathrm{NaCl} \text { ) was dispensed using a } \\
\text { BioRAPTR (Beckman Coulter). Total reaction } \\
\text { volume of } 50 \mu \mathrm{L} \text {. }\end{array}$ \\
\hline 4 & Incubated at RT for $1 \mathrm{hr}$ & $\begin{array}{l}\text { Final assay conditions are } 10 \mu \mathrm{M} \text { peptide and } \\
0.4 \mu \mathrm{M} \text { TMPRSS} 2 \text { in assay buffer ( } 50 \mathrm{mM} \text { Tris- } \\
\mathrm{HCl} \mathrm{pH} 8,150 \mathrm{mM} \mathrm{NaCl})\end{array}$ \\
\hline 5 & $\begin{array}{l}\text { Addition of quench solution (50 } \\
\mu \mathrm{L})\end{array}$ & $\begin{array}{l}\text { Quench solution ( } 90: 10 \mathrm{ACN}: \mathrm{H}_{2} \mathrm{O}+0.1 \% \\
\text { formic acid }+100 \mathrm{nM} \text { of IS }\left(\mathrm{Cbz}-\mathrm{SK}-\left\{{ }^{13} \mathrm{C}_{5}{ }^{15} \mathrm{~N}\right.\right. \\
\text { Pro\}-SKR. Total volume of } 100 \mu \mathrm{L} .\end{array}$ \\
\hline 6 & Dilution of reaction (10-fold) & $\begin{array}{l}\text { Dilution of reaction } 10 \text {-fold using } 20 \mathrm{mM} \\
\text { ammonium formate }+0.1 \% \text { formic acid. }\end{array}$ \\
\hline 7 & $\begin{array}{l}\text { Measure mass detection on } \\
\text { SciEx } 6500\end{array}$ & $\begin{array}{l}\text { The LC buffers were A: } 0.1 \% \text { difluoroacetic } \\
\text { acid in water and B: acetonitrile, and a } \\
\text { gradient elution was used that went from } 5 \% \\
\text { Buffer B to } 90 \% \text { Buffer B in } 0.5 \text { min with a } \\
\text { flow rate of } 0.70 \mathrm{~mL} / \mathrm{min} \text {. The product } \\
\text { cleavage fragment (Cbz-SKPSKR): } 418.8 / 702.4 \\
\mathrm{~m} / \mathrm{z} \text {. The IS cleavage fragment: } 421.64 / 708.24\end{array}$ \\
\hline
\end{tabular}


bioRxiv preprint doi: https://doi.org/10.1101/2022.02.04.479134; this version posted February 7,2022 . The copyright holder for this preprint (which was not certified by peer review) is the author/funder, who has granted bioRxiv a license to display the preprint in perpetuity. It is made available under aCC-BY 4.0 International license.

Table 4. Compounds having confirmed inhibition of TMPRSS2 in both biochemical assays and in the cellular assay.

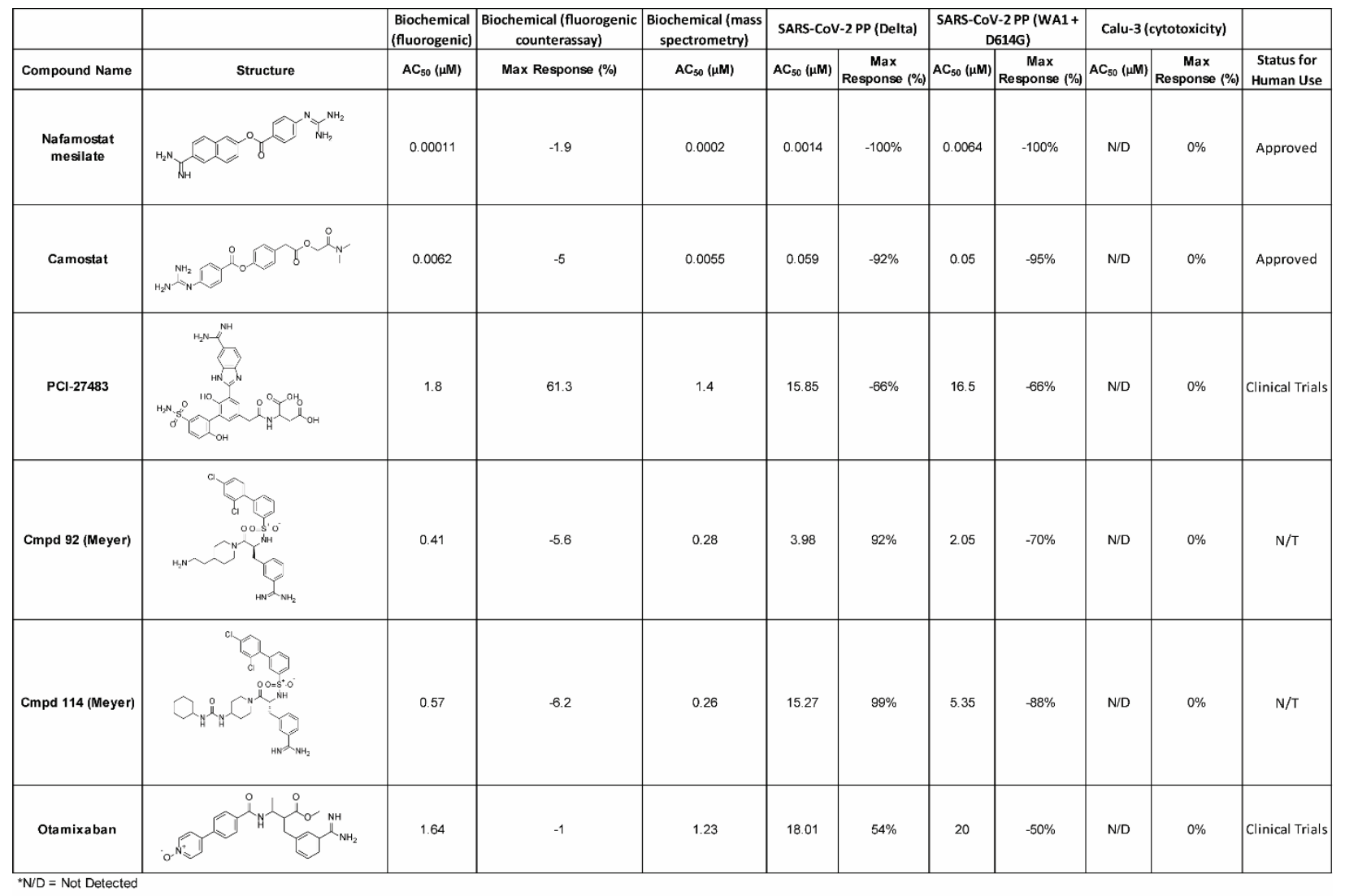


A)
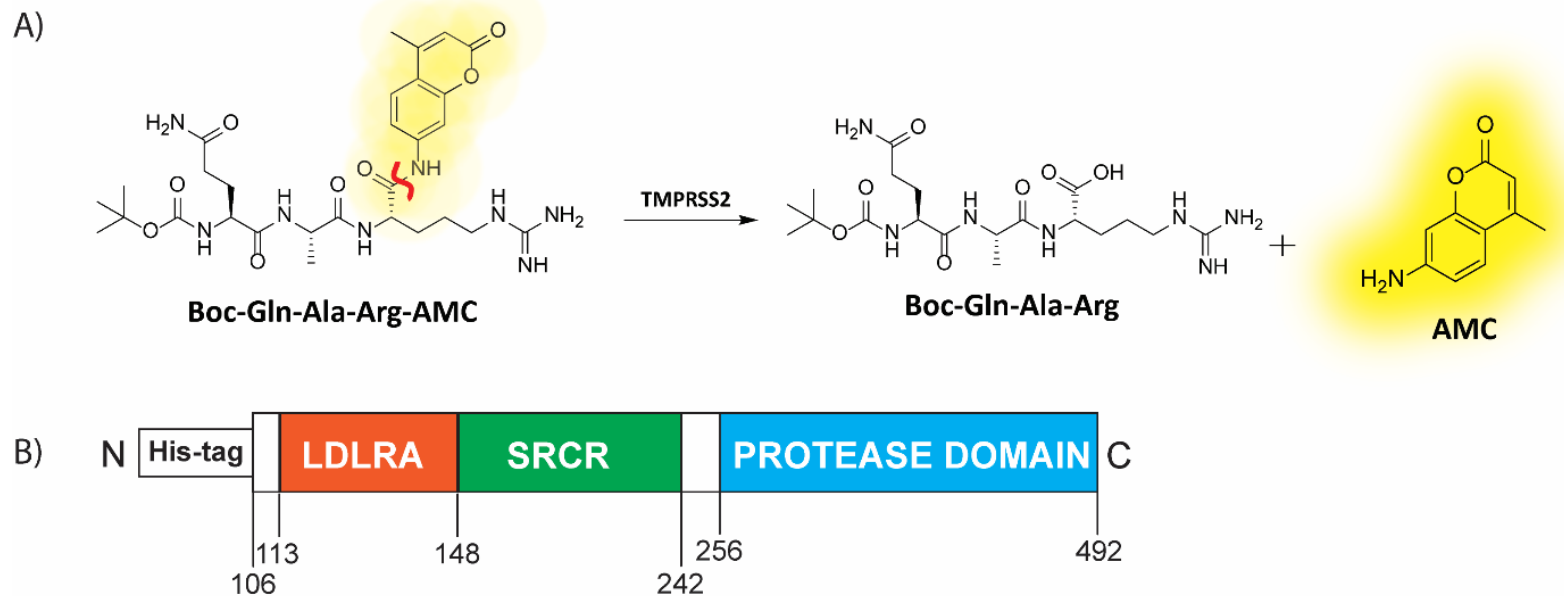

Figure 1. (A) Scheme displaying the enzymatic assay principle for the fluorogenic peptide substrate. The fluorogenic peptide substrate Boc-Gln-Ala-Arg-AMC has low fluorescence compared to the fluorescent 7-amino-4-methylcoumarin (AMC), which is released upon proteolytic cleavage. The scissile bond is indicated in red. (B) Schematic of the truncated yeast-expressed recombinant TMPRSS2 used in the fluorogenic assay, containing the low-density lipoprotein receptor A (LDLRA) domain, scavenger receptor cysteine-rich (SRCR) domain and protease domain. 
A)

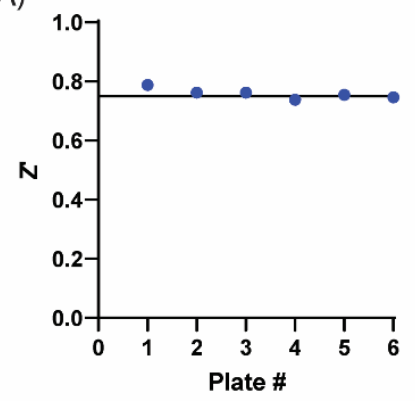

C)

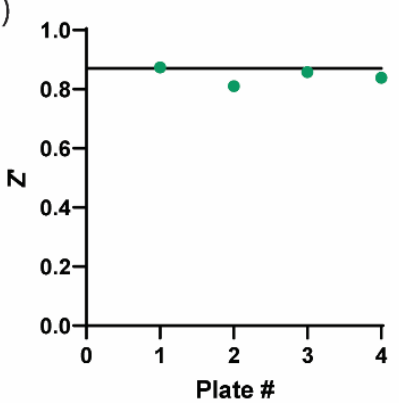

NPC

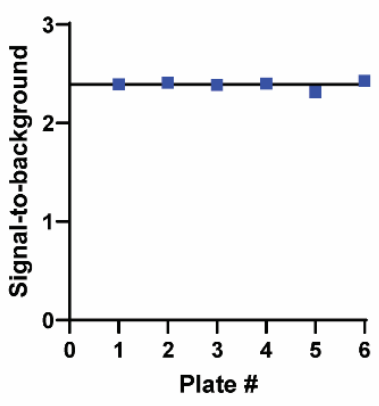

PIL

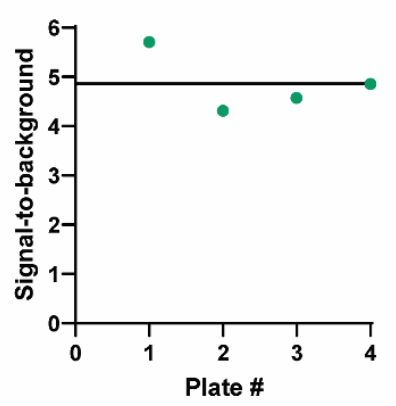

B)

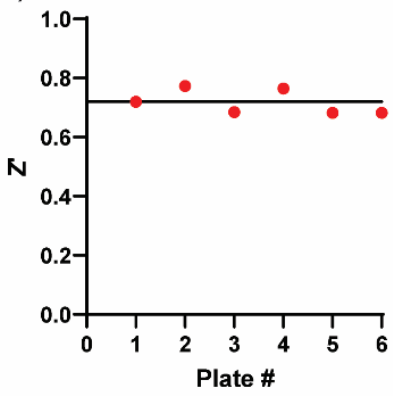

MIPE

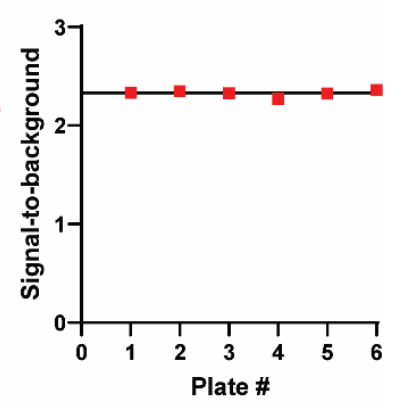

Figure 2. Assay performance for primary screening of the compound libraries in the TMPRSS2 fluorogenic biochemical activity assay. $Z$ ' scores and signal-to-background values are plotted as data points for each plate. There were 32 positive and 64 negative control wells on each 1536-well plate. (A) NCATS Pharmaceutical Collection (NPC), 2,678 compounds, (B) Mechanism Interrogation Plate (MIPE) library, 2,480 compounds and (C) protease inhibitor library (PIL), 872 compounds. Black horizontal lines represent the mean values. 
A)

SARS-CoV-2

Spike Protein

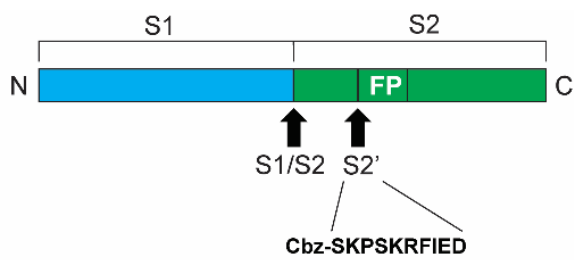

B)

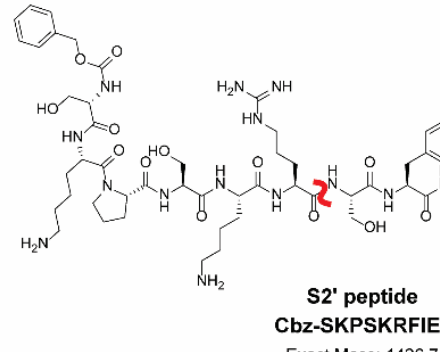

C)

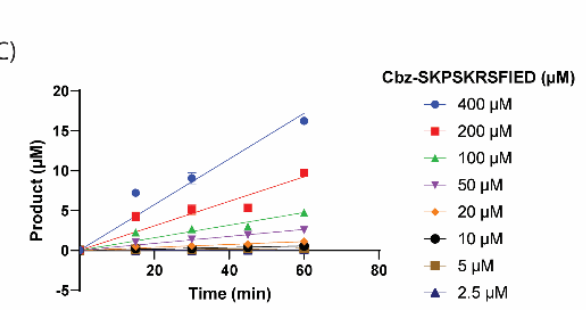

D)
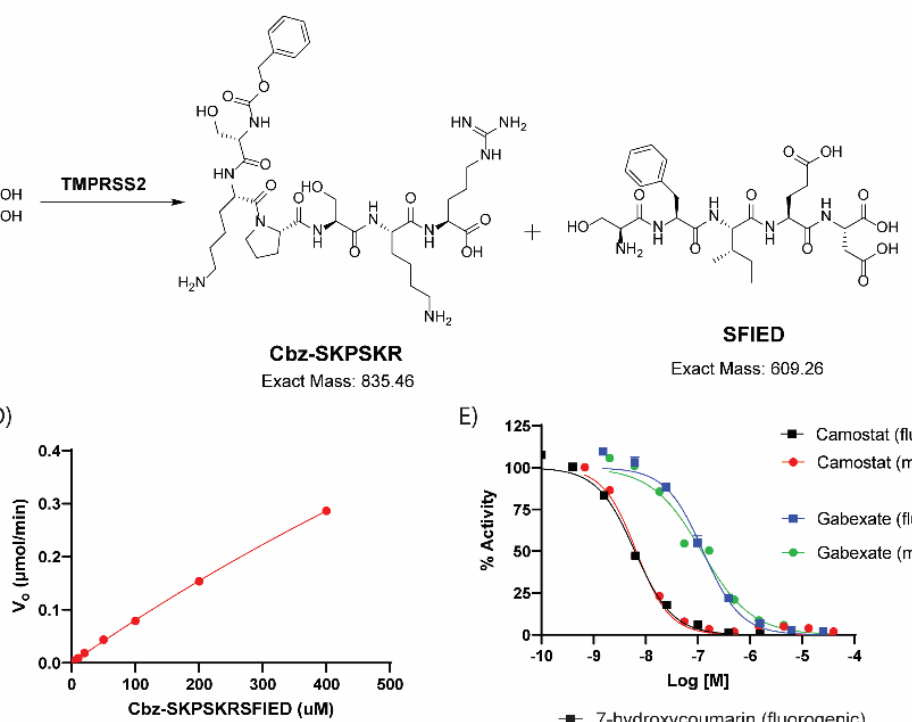

CbZ-SKPSKRFIED

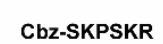

SFIED

F)
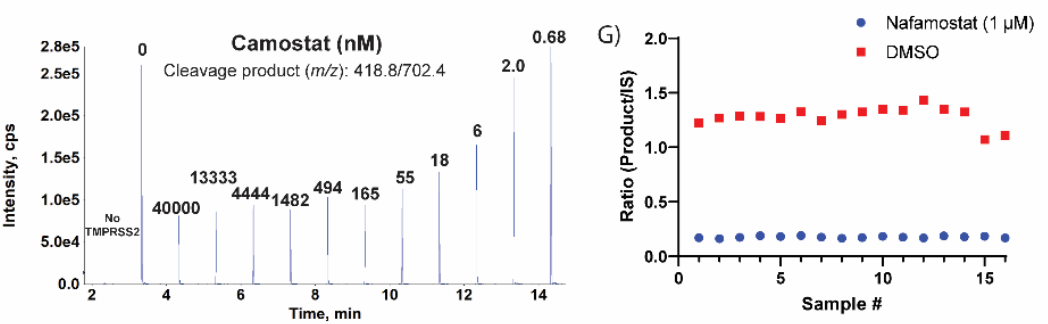

E)

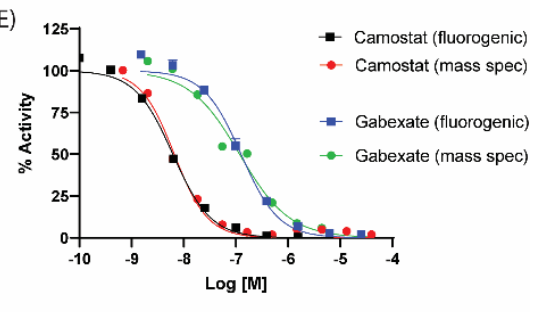

- 7-hydroxycoumarin (fluorogenic)

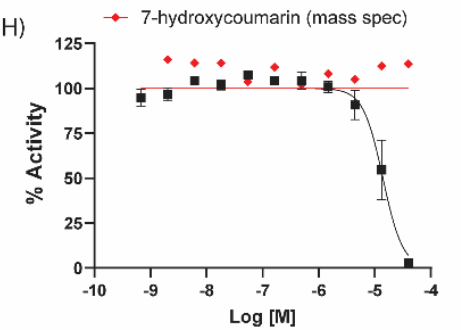

Figure 3. Label-free mass spectrometry biochemical assay. (A) Peptide derived from the known S2' cleavage site of SARS-CoV-2 Spike (S) protein. (B) Scheme displaying the enzymatic assay principle for the unlabeled peptide substrate. The unlabeled peptide substrate, Cbz-SKPSKRFIED, is cleaved by TMPRSS2 to create two cleavage products, Cbz-SKPSKR and SFIED. The scissile bond is indicated in red. (C) Initial velocity $\left(V_{0}\right)$ was calculated for each substrate concentration by plotting product formation vs time. (D) The $V_{0}$ for each concentration were plotted against the various substrate concentrations to obtain the $\mathrm{V}_{\max }$ and $\mathrm{K}_{\mathrm{m}}$. $\mathrm{V}_{\max }: 1.95 \mu \mathrm{mol} / \mathrm{min}$ and $\mathrm{K}_{\mathrm{m}}$ : estimated $2320 \mu \mathrm{M}$. (E) Comparison of TMPRSS2 fluorogenic detection and mass spectrometry detection assays by assessing dose-response inhibition by camostat and gabexate. (F) Mass spectrometry traces of the cleavage product (m/z: 418.8/702.4) showing that addition of camostat prevents product formation in dose-response. Each peak is labeled with the concentration of camostat (nM) for that condition. (G) Assay performance from the mass spectrometry detection assay when screening the hits identified from the primary screening. $Z^{\prime}$ of 0.71 and S:B of 7.37. (H) Dose-response inhibition of 7-hydroxycoumarin against TMPRSS2 in both fluorogenic and mass spectrometry detection assays showing the fluorescent molecule as a false-positive hit in the fluorogenic assay, but not interfering with the mass spectrometry detection assay. 
bioRxiv preprint doi: https://doi.org/10.1101/2022.02 04 479134. this version posted February 7,2022. The copyright holder for this preprint (which was not certified by peer review) is the author/funder, who has granted bioRxiv a license to display the preprint in perpetuity. It is made available under aCC-BY 4.0 International license.

\section{A) PP Production}

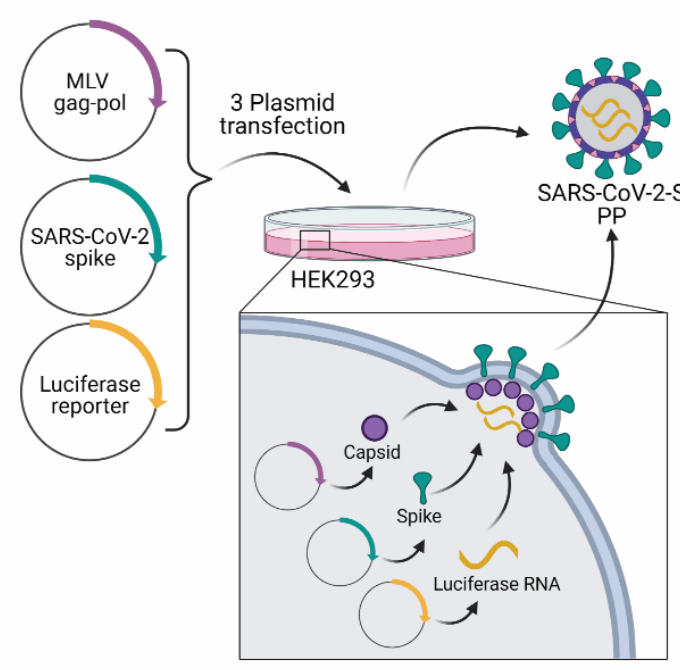

C)

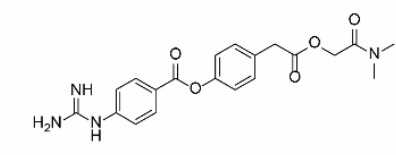

$\star$ PP entry - WA1 + D614G

$\bullet$ PP entry - Delta

- Cytotoxicity

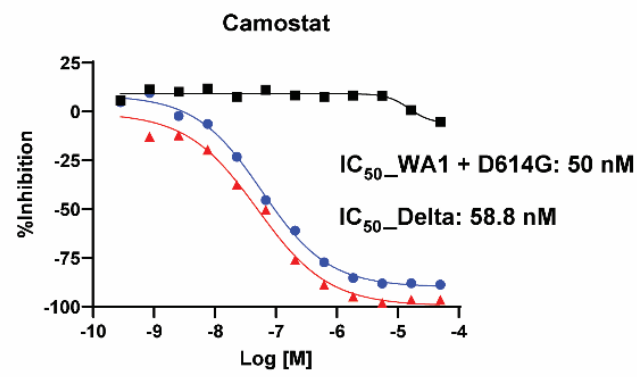

E)

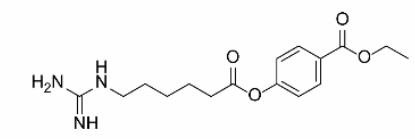

Gabexate

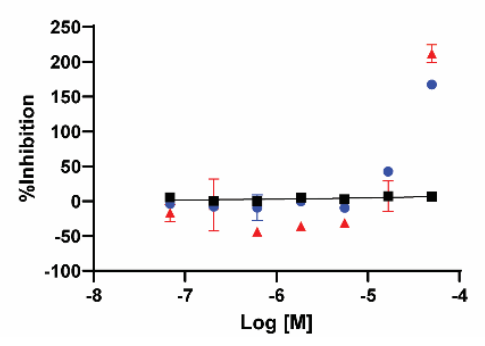

B) PP Entry Assay

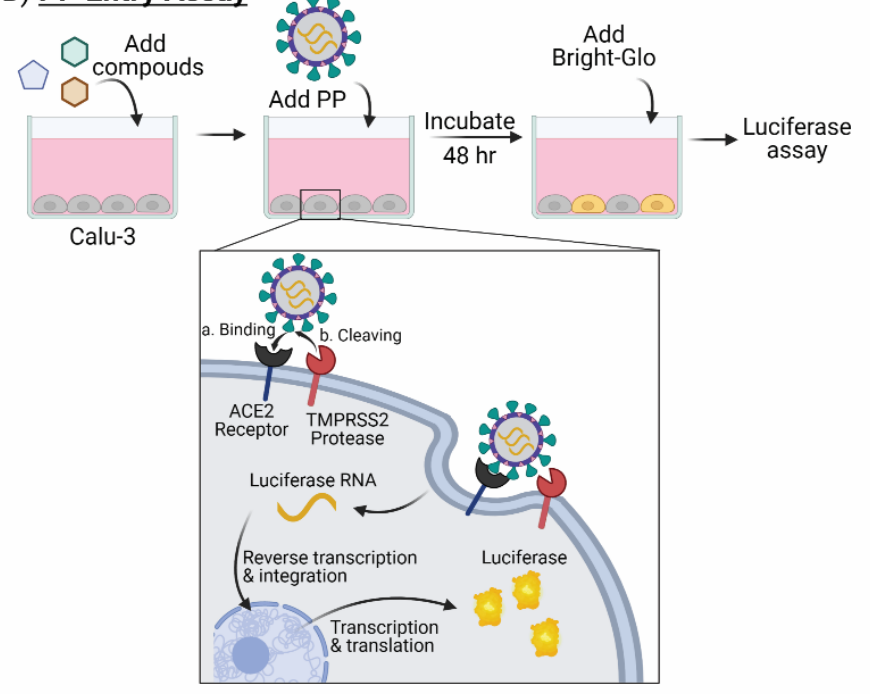

D)
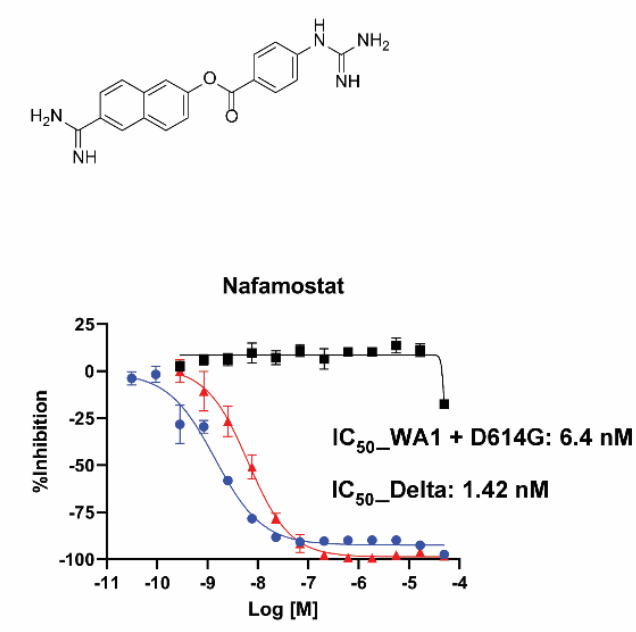

F)
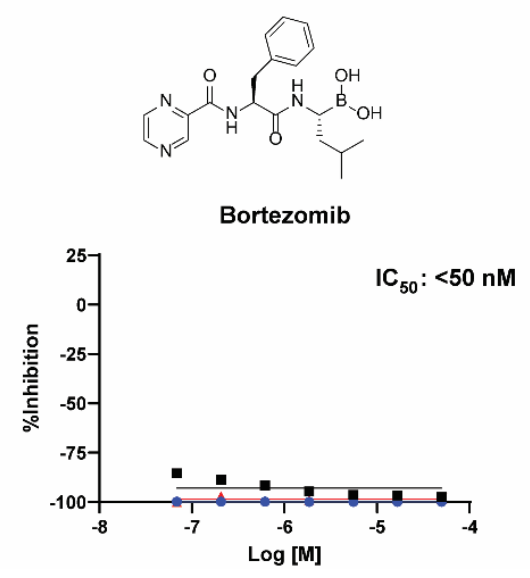
Figure 4. Cell-based pseudotyped particle assay. (A) Pseudotyped particle production. Three plasmids (pCMV-MLVgag-pol, pcDNA-SARS-CoV-2 spike, and pTG-Luciferase) are co-transfected into HEK-293T/17 cells. The plasmids express MLV core gag-pol polyprotein, SARS-CoV-2 spike glycoproteins, and luciferase RNAs, which together assemble into pseudotyped particles. (B) Pseudotyped particle assay scheme. Order of addition of reagents to Calu-3 cells is 1 . compounds, 2. pseudotyped particles and 3. the Promega reagent Bright-Glo. Once cell entry of pseudotyped particle occurs, RNAs of pseudotyped particles are released into the cell, where they are reverse transcribed into DNAs, integrated into the genome and express luciferase reporter enzyme. The amount of luminescence following addition of Bright-Glo is proportional to the amount of pseudotyped particle entry into cells. Illustration was made with BioRender. Activity of clinically-approved inhibitors in prevention of pseudotyped particle entry using the Spike sequence from the Delta variant (blue), WA1 + D614G variant (red) and cytotoxicity counter-assay (black). The molecular structures and dose-response inhibition of particle entry by (C) camostat, (D) nafamostat, (E) gabexate, (F) bortezomib. The calculated concentrations required for $50 \%$ inhibition $\left(\mathrm{IC}_{50}\right)$ are displayed in $\mu \mathrm{M}$.

\section{Supporting Information}

The Supporting Information is available free of charge at _.

Supplementary Table 1: A list of the 27 compounds as confirmed hits following screening in the fluorogenic assay and fluorescence counterassay.

\section{Acknowledgement}

The authors acknowledge James Inglese for helpful discussions on enzyme kinetics. This work was supported by the National Center for Advancing Translational Sciences, Division of Preclinical Innovation. 


\section{References}

1. Wang, M.; Cao, R.; Zhang, L.; Yang, X.; Liu, J.; Xu, M.; Shi, Z.; Hu, Z.; Zhong, W.; Xiao, G., Remdesivir and chloroquine effectively inhibit the recently emerged novel coronavirus (2019-nCoV) in vitro. Cell Research 2020, 30 (3), 269-271.

2. $\quad$ Eastman, R. T.; Roth, J. S.; Brimacombe, K. R.; Simeonov, A.; Shen, M.; Patnaik, S.; Hall, M. D., Remdesivir: A Review of Its Discovery and Development Leading to Emergency Use Authorization for Treatment of COVID-19. ACS Central Science 2020, 6 (5), 672-683.

3. Baggen, J.; Vanstreels, E.; Jansen, S.; Daelemans, D., Cellular host factors for SARS-CoV-2 infection. Nature Microbiology 2021, 6 (10), 1219-1232.

4. Hall, M. D.; Anderson, J. M.; Anderson, A.; Baker, D.; Bradner, J.; Brimacombe, K. R.; Campbell, E. A.; Corbett, K. S.; Carter, K.; Cherry, S.; Chiang, L.; Cihlar, T.; de Wit, E.; Denison, M.; Disney, M.; Fletcher, C. V.; Ford-Scheimer, S. L.; Götte, M.; Grossman, A. C.; Hayden, F. G.; Hazuda, D. J.; Lanteri, C. A.; Marston, H.; Mesecar, A. D.; Moore, S.; Nwankwo, J. O.; O’Rear, J.; Painter, G.; Singh Saikatendu, K.; Schiffer, C. A.; Sheahan, T. P.; Shi, P.-Y.; Smyth, H. D.; Sofia, M. J.; Weetall, M.; Weller, S. K.; Whitley, R.; Fauci, A. S.; Austin, C. P.; Collins, F. S.; Conley, A. J.; Davis, M. I., Report of the National Institutes of Health SARS-CoV-2 Antiviral Therapeutics Summit. The Journal of Infectious Diseases 2021, 224 (Supplement_1), S1-S21.

5. Hoffmann, M.; Hofmann-Winkler, H.; Smith, J. C.; Krüger, N.; Arora, P.; Sørensen, L. K.; Søgaard, O. S.; Hasselstrøm, J. B.; Winkler, M.; Hempel, T.; Raich, L.; Olsson, S.; Danov, O.; Jonigk, D.; Yamazoe, T.; Yamatsuta, K.; Mizuno, H.; Ludwig, S.; Noé, F.; Kjolby, M.; Braun, A.; Sheltzer, J. M.; PöhImann, S., Camostat mesylate inhibits SARS-CoV-2 activation by TMPRSS2-related proteases and its metabolite GBPA exerts antiviral activity. EBioMedicine 2021, 65, 103255.

6. Bertram, S.; Heurich, A.; Lavender, H.; Gierer, S.; Danisch, S.; Perin, P.; Lucas, J. M.; Nelson, P. S.; Pöhlmann, S.; Soilleux, E. J., Influenza and SARS-Coronavirus Activating Proteases TMPRSS2 and HAT Are Expressed at Multiple Sites in Human Respiratory and Gastrointestinal Tracts. PLOS ONE 2012, 7 (4), e35876.

7. Jankun, J., COVID-19 pandemic; transmembrane protease serine 2 (TMPRSS2) inhibitors as potential drugs. Translation: The University of Toledo Journal of Medical Sciences 2020, 7, 1 - 5.

8. Bestle, D.; Heindl, M. R.; Limburg, H.; Van Lam van, T.; Pilgram, O.; Moulton, H.; Stein, D. A.; Hardes, K.; Eickmann, M.; Dolnik, O.; Rohde, C.; Klenk, H.-D.; Garten, W.; Steinmetzer, T.; BöttcherFriebertshäuser, E., TMPRSS2 and furin are both essential for proteolytic activation of SARS-CoV-2 in human airway cells. Life Science Alliance 2020, 3 (9), e202000786.

9. $\quad$ Peacock, T. P.; Goldhill, D. H.; Zhou, J.; Baillon, L.; Frise, R.; Swann, O. C.; Kugathasan, R.; Penn, R.; Brown, J. C.; Sanchez-David, R. Y.; Braga, L.; Williamson, M. K.; Hassard, J. A.; Staller, E.; Hanley, B.; Osborn, M.; Giacca, M.; Davidson, A. D.; Matthews, D. A.; Barclay, W. S., The furin cleavage site in the SARS-CoV-2 spike protein is required for transmission in ferrets. Nature Microbiology 2021, 6 (7), 899-909.

10. Zang, R.; Castro, M. F. G.; McCune, B. T.; Zeng, Q.; Rothlauf, P. W.; Sonnek, N. M.; Liu, Z.; Brulois, K. F.; Wang, X.; Greenberg, H. B.; Diamond, M. S.; Ciorba, M. A.; Whelan, S. P. J.; Ding, S., TMPRSS2 and TMPRSS4 promote SARS-CoV-2 infection of human small intestinal enterocytes. Science Immunology 2020, 5 (47), eabc3582.

11. Shrimp, J. H.; Kales, S. C.; Sanderson, P. E.; Simeonov, A.; Shen, M.; Hall, M. D., An Enzymatic TMPRSS2 Assay for Assessment of Clinical Candidates and Discovery of Inhibitors as Potential Treatment of COVID-19. ACS Pharmacology \& Translational Science 2020, 3 (5), 997-1007.

12. Hu, X.; Shrimp, J. H.; Guo, H.; Xu, M.; Chen, C. Z.; Zhu, W.; Zakharov, A. V.; Jain, S.; Shinn, P.; Simeonov, A.; Hall, M. D.; Shen, M., Discovery of TMPRSS2 Inhibitors from Virtual Screening as a Potential Treatment of COVID-19. ACS Pharmacology \& Translational Science 2021, 4 (3), 1124-1135. 
13. Hempel, T.; Elez, K.; Krüger, N.; Raich, L.; Shrimp, J. H.; Danov, O.; Jonigk, D.; Braun, A.; Shen, M.; Hall, M. D.; Pöhlmann, S.; Hoffmann, M.; Noé, F., Synergistic inhibition of SARS-CoV-2 cell entry by otamixaban and covalent protease inhibitors: pre-clinical assessment of pharmacological and molecular properties. Chemical Science 2021, 12 (38), 12600-12609.

14. Nurit P Azouz, A. M. K., Victoria Callahan, Ivan V Akhrymuk, Katarina Elez, Lluis Raich, Brandon M Henry, Justin L Benoit, Stefanie W Benoit, Frank Noe, Kylene Kehn-Hall, Marc E Rothenberg, Alpha 1 Antitrypsin is an Inhibitor of the SARS-CoV-2-Priming Protease TMPRSS2. Pathogens And Immunity 2021, 6 (1), 55-74.

15. Kastenhuber, E. R.; Jaimes, J. A.; Johnson, J. L.; Mercadante, M.; Muecksch, F.; Weisblum, Y.; Bram, Y.; Schwartz, R. E.; Whittaker, G. R.; Cantley, L. C., Coagulation factors directly cleave SARS-CoV-2 spike and enhance viral entry. bioRxiv 2021, 2021.03.31.437960.

16. Chen, Y.; Lear, T. B.; Evankovich, J. W.; Larsen, M. B.; Lin, B.; Alfaras, I.; Kennerdell, J. R.; Salminen, L.; Camarco, D. P.; Lockwood, K. C.; Tuncer, F.; Liu, J.; Myerburg, M. M.; McDyer, J. F.; Liu, Y.; Finkel, T.; Chen, B. B., A high-throughput screen for TMPRSS2 expression identifies FDA-approved compounds that can limit SARS-CoV-2 entry. Nature Communications 2021, 12 (1), 3907.

17. Hoffmann, M.; Kleine-Weber, H.; Schroeder, S.; Krüger, N.; Herrler, T.; Erichsen, S.; Schiergens, T. S.; Herrler, G.; Wu, N.-H.; Nitsche, A.; Müller, M. A.; Drosten, C.; Pöhlmann, S., SARSCoV-2 Cell Entry Depends on ACE2 and TMPRSS2 and Is Blocked by a Clinically Proven Protease Inhibitor. Cell 2020, 181 (2), 271-280.e8.

18. Chen, C. Z.; Xu, M.; Pradhan, M.; Gorshkov, K.; Petersen, J. D.; Straus, M. R.; Zhu, W.; Shinn, P.; Guo, H.; Shen, M.; Klumpp-Thomas, C.; Michael, S. G.; Zimmerberg, J.; Zheng, W.; Whittaker, G. R., Identifying SARS-CoV-2 Entry Inhibitors through Drug Repurposing Screens of SARS-S and MERS-S Pseudotyped Particles. ACS Pharmacology \& Translational Science 2020, 3 (6), 1165-1175.

19. NIH Clinical Trials of Nafamostat for COVID-19. https://clinicaltrials.gov/ct2/results?cond=COVID-19\&term=nafamostat\&cntry=\&state=\&city=\&dist=.

20. NIH Clinical Trials for Camostat for COVID-19. https://clinicaltrials.gov/ct2/results?cond=COVID-19\&term=camostat\&cntry=\&state=\&city=\&dist= 21. Meyer, D.; Sielaff, F.; Hammami, M.; Böttcher-Friebertshäuser, E.; Garten, W.; Steinmetzer, T., Identification of the first synthetic inhibitors of the type II transmembrane serine protease TMPRSS2 suitable for inhibition of influenza virus activation. Biochemical Journal 2013, 452 (2), 331-343.

22. Inglese, J.; Auld, D. S.; Jadhav, A.; Johnson, R. L.; Simeonov, A.; Yasgar, A.; Zheng, W.; Austin, C. P., Quantitative high-throughput screening: A titration-based approach that efficiently identifies biological activities in large chemical libraries. Proceedings of the National Academy of Sciences 2006, 103 (31), 11473-11478.

23. Brimacombe, K. R.; Zhao, T.; Eastman, R. T.; Hu, X.; Wang, K.; Backus, M.; Baljinnyam, B.; Chen, C. Z.; Chen, L.; Eicher, T.; Ferrer, M.; Fu, Y.; Gorshkov, K.; Guo, H.; Hanson, Q. M.; Itkin, Z.; Kales, S. C.; Klumpp-Thomas, C.; Lee, E. M.; Michael, S.; Mierzwa, T.; Patt, A.; Pradhan, M.; Renn, A.; Shinn, P.; Shrimp, J. H.; Viraktamath, A.; Wilson, K. M.; Xu, M.; Zakharov, A. V.; Zhu, W.; Zheng, W.; Simeonov, A.; Mathé, E. A.; Lo, D. C.; Hall, M. D.; Shen, M., An OpenData portal to share COVID-19 drug repurposing data in real time. bioRxiv 2020.

24. Thorne, N.; Auld, D. S.; Inglese, J., Apparent activity in high-throughput screening: origins of compound-dependent assay interference. Current Opinion in Chemical Biology 2010, 14 (3), 315-324.

25. Adam, G. C.; Meng, J.; Rizzo, J. M.; Amoss, A.; Lusen, J. W.; Patel, A.; Riley, D.; Hunt, R.; Zuck, P.; Johnson, E. N.; Uebele, V. N.; Hermes, J. D., Use of High-Throughput Mass Spectrometry to Reduce False Positives in Protease uHTS Screens. Journal of Biomolecular Screening 2014, 20 (2), 212-222.

26. Acker, M. G.; Auld, D. S., Considerations for the design and reporting of enzyme assays in highthroughput screening applications. Perspectives in Science 2014, 1 (1), 56-73. 
27. Yamamoto, M.; Kiso, M.; Sakai-Tagawa, Y.; Iwatsuki-Horimoto, K.; Imai, M.; Takeda, M.; Kinoshita, N.; Ohmagari, N.; Gohda, J.; Semba, K.; Matsuda, Z.; Kawaguchi, Y.; Kawaoka, Y.; Inoue, J.i., The Anticoagulant Nafamostat Potently Inhibits SARS-CoV-2 S Protein-Mediated Fusion in a Cell Fusion Assay System and Viral Infection In Vitro in a Cell-Type-Dependent Manner. Viruses 2020, 12 (6), 629.

28. Hoffmann, M.; Schroeder, S.; Kleine-Weber, H.; Müller, M. A.; Drosten, C.; Pöhlmann, S., Nafamostat Mesylate Blocks Activation of SARS-CoV-2: New Treatment Option for COVID-19. Antimicrobial Agents and Chemotherapy 2020, 64 (6), e00754-20.

29. Morrissey, J. H.; Neuenschwander, P. F.; Huang, Q.; McCallum, C. D.; Su, B.; Johnson, A. E., Factor VIla-tissue factor: functional importance of protein-membrane interactions. Thromb Haemost 1997, 78 (1), 112-6.

30. Hembrough, T. A.; Swartz, G. M.; Papathanassiu, A.; Vlasuk, G. P.; Rote, W. E.; Green, S. J.; Pribluda, V. S., Tissue Factor/Factor VIla Inhibitors Block Angiogenesis and Tumor Growth Through a Nonhemostatic Mechanism. Cancer Research 2003, 63 (11), 2997.

31. Ramanathan, R. K.; Thomas, G. W.; Khorana, A. A.; Shah, S.; Zhou, C.; Wong, S.; Cole Jr, G.; James, D.; Gabrail, N. Y., A Phase 2 Study of PCl-27483, a Factor VIlla Inhibitor in Combination with Gemcitabine for Advanced Pancreatic Cancer. Oncology 2019, 96 (4), 217-222.

32. Sun, Y. J.; Velez, G.; Parsons, D. E.; Li, K.; Ortiz, M. E.; Sharma, S.; McCray, P. B., Jr.; Bassuk, A. G.; Mahajan, V. B., Structure-based phylogeny identifies avoralstat as a TMPRSS2 inhibitor that prevents SARS-CoV-2 infection in mice. The Journal of Clinical Investigation 2021, 131 (10).

33. Guertin, K. R.; Choi, Y. M., The discovery of the Factor Xa inhibitor otamixaban: from lead identification to clinical development. Curr Med Chem 2007, 14 (23), 2471-81.

34. Guertin, K. R.; Gardner, C. J.; Klein, S. I.; Zulli, A. L.; Czekaj, M.; Gong, Y.; Spada, A. P.; Cheney, D. L.; Maignan, S.; Guilloteau, J.-P.; Brown, K. D.; Colussi, D. J.; Chu, V.; Heran, C. L.; Morgan, S. R.; Bentley, R. G.; Dunwiddie, C. T.; Leadley, R. J.; Pauls, H. W., Optimization of the $\beta$-Aminoester class of factor Xa inhibitors. part 2: Identification of FXV673 as a potent and selective inhibitor with excellent In vivo anticoagulant activity. Bioorganic \& Medicinal Chemistry Letters 2002, 12 (12), 1671-1674.

35. Steg, P. G.; Mehta, S. R.; Pollack, C. V., Jr.; Bode, C.; Cohen, M.; French, W. J.; Hoekstra, J.; Rao, S. V.; Ruzyllo, W.; Ruiz-Nodar, J. M.; Sabaté, M.; Widimsky, P.; Kiss, R. G.; Navarro Estrada, J. L.; Hod, H.; Kerkar, P.; Guneri, S.; Sezer, M.; Ruda, M.; Nicolau, J. C.; Cavallini, C.; Ebrahim, I.; Petrov, I.; Kim, J. H.; Jeong, M. H.; Ramos Lopez, G. A.; Laanmets, P.; Kovar, F.; Gaudin, C.; Fanouillere, K. C.; Minini, P.; Hoffman, E. B.; Moryusef, A.; Wiviott, S. D.; Sabatine, M. S., Anticoagulation with otamixaban and ischemic events in non-ST-segment elevation acute coronary syndromes: the TAO randomized clinical trial. Jama 2013, 310 (11), 1145-55.

36. Rensi S, K. A., Lo Y-C, Derry A, McInnes G, Liu T, Altman R. , Homology Modeling of TMPRSS2 Yields Candidate Drugs That May Inhibit Entry of SARS-CoV-2 into Human Cells. ChemRxiv 2020. 